\section{MAKNA BUNGA BANK: SEBUAH KAJIAN INTERAKSIONISME SIMBOLIK}

\author{
T.W. Oktavendi \\ Universitas Brawijaya Malang \\ E-mail: t.w.oktavendi@gmail.com
}

\title{
Abstract
}

The aim of this research is to understand how the meaning of bank interest according to the manager PT CTU. This research uses symbolic interactionism approach. Through five informants who have a position in PT CTU, researcher found the duality of meaning that contradict each other. The duality of the meaning is (1) bank interest in return for services and (2) bank interest as a liability for social activities. The dominant meaning in the contradiction is bank interest as a liability for social activities due to the power of shareholders.

Keywords: Symbolic Interactionism, The Meaning of Bank Interest, Domination of Shareholder.

\section{PENDAHULUAN}

Perkembangan ilmu akuntansi pada era globalisasi ini sangatlah cepat. Perkembangan ilmu ini disertai dengan adanya berbagai perdebatan oleh para peneliti di bidang akuntansi. Munculnya lembaga keuangan yaitu bank, memicu banyak sekali perdebatan khususnya dari sisi syariahnya. Produk-produk yang ditawarkan oleh bank mulai menjadi perdebatan. Bunga tabungan termasuk dalam salah satu perdebatan pada aspek hukum halal-haramnya.

Masyarakat atau nasabah yang memiliki dana simpanan di bank akan mendapatkan beberapa keuntungan dari pihak bank. Salah satu keuntungan dari aktivitas menyimpan uang di bank adalah bagi-hasil, jika menggunakan layanan bank syariah. Di sisi lain, bank konvensional memberikan bunga simpanan sebagai return kepada nasabahnya. Chong \& Liu (2009) menyatakan bahwa salah satu perbedaan antara bank konvensional dengan bank syariah terletak pada interest (riba). Dalam islam, bank tidak diperbolehkan menawarkan fixed rate baik dalam hal simpanan maupun pinjaman. Syariah dengan jelas melarang dan mengharamkan adanya transaksi riba (Abedifar, Molyneux, \& Tarazi, 2013; Ahmad \& Hassan, 2007; Beck, Demirgüç-Kunt, \& Merrouche, 2013). Perbedaan antara syariah dan konvensional terkait dengan bunga bank tentu sampai pada perlakuan akuntansinya.

Penelitian tentang praktik perlakuan akuntansi pendapatan bunga bank (konvensional) atau dana non halal (syariah) telah banyak dilakukan. Penelitian tersebut dilakukan baik dalam konteks akuntansi konvensional maupun syariah. Pada badan usaha berbasis konvensional, pada umumnya mereka mengelompokkan bunga tabungan, jasa giro, maupun bunga deposito kedalam pos pendapatan bunga atau pendapatan di luar usaha. PSAK no 23 menyatakan bahwa pendapatan dibagi atas tiga jenis, yaitu pendapatan karena penjualan barang, penjualan jasa dan pendapatan atas Bunga, Royalti dan Dividen.

Sebuah jurnal internasional yang ditulis oleh Bohusova \& Nerudova (2009) mencoba membandingkan revenue recognition antara US GAAP dengan IFRS. Mereka menemukan perbedaan dalam konteks pengakuan pendapatan. US GAAP menetapkan bahwa pendapatan harus sudah terealisasi dan diperoleh, sedangkan IFRS, apabila di masa mendatang dapat memberikan masa manfaat maka bisa

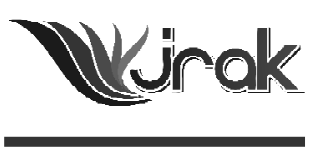

Jurnal Reviu Akuntansi dan Keuangan ISSN: 2088-0685 Vol.5 No. 2, Oktober 2015 Pp 769-780 
Makna

Bunga

Bank...

770 diakui serta tentunya dapat diukur secara andal. Masalah pengukuran baik US GAAP maupun IFRS sama, menggunakan fair value ataupun kas ataupun setara kas.

Penelitian tentang perlakuan akuntansi konvensional pendapatan bunga dilakukan oleh Septiono et al. (2015). Dalam penelitian tentang pengakuan pendapatan dan beban tersebut, mereka menggunakan PT Petroksida Gresik sebagai objek penelitian. Metode yang digunakan adalah komparasi antara data dengan standar akuntansi. Hasil yang mereka temukan terkait dengan pendapatan bunga ialah saldo pendapatan bunga bank diakui sesuai dengan tanggal rekening Koran dan sebagai akun pendapatan lain-lain.

Penelitian lain tentang pendapatan bunga dalam konteks akuntansi konvensional adalah penelitian yang dilakukan Samsu (2013). Dia mencoba menganalisis pengukuran dan pengakuan pendapatan di PT Misa Utara Mando. Metode yang digunakan sama dengan penelitian Septiono et al. (2015) yaitu membandingkan standar akuntansi konvensional dengan data penelitian. Hasil penelitian yang ia peroleh ialah pengakuan jasa giro (pendapatan bunga) menggunakan accrual basis dan masuk ke dalam akun pendapatan operasional. Oleh karena itu, peneliti tersebut menyarankan untuk mencatat pendapatan bunga kedalam akun pendapatan non operasional. Pengukuran pendapatan bunga PT Misa Utara Manado menggunakan metode setara kas.

Refleksi peneliti terhadap kedua penelitian di atas adalah bahwa perusahaan berbentuk PT cenderung menggunakan konsep konvensional. Perusahaan-perusahaan tersebut menganggap bahwa pendapatan bunga adalah halal. Oleh karena itu, mereka memasukkannya ke dalam komponen laba/rugi. Peneliti tidak menemukan penelitian pada perusahaan berbentuk Perseroan Terbatas (PT) yang menggunakan basis (yang berbau) syariah dalam memperlakukan pendapatan bunga bank.

Pada instansi/badan usaha berbasis islam, seperti perbankan syariah, mereka mengelompokkan dana haram kedalam pos pendapatan non halal dan memisahkannya dari laporan pertanggungjawaban atau laporan laba rugi (PSAK Nomor 101). PAPSI (Pedoman Akuntansi Perbankan Syariah Indonesia) tahun 2013 juga menjelaskan bahwa pendapatan jasa giro yang diterima dari bank umum konvensional diakui dalam Laporan Sumber dan Penggunaan Dana Qardhul Hasan pada pos pendapatan non halal sebesar nilai nominal yang diterima.

Fakta yang terjadi dapat kita lihat pada beberapa penelitan tentang penerapan pendapatan non halal. Roziq \& Yanti (2013) dalam penelitiannya menjelaskan bahwa Lembaga Amil Zakat Yatim Mandiri dan DD Surabaya tidak memisahkan antara dana non halal dengan dana lainnya. LAZ Yatim Mandiri menjadikan satu dana non halal dengan dana lainnya kedalam akun saldo dana amil. Sedangkan LAZ DD Surabaya, mereka mengelompokkan dana non halal dan dana lainnya kedalam akun dana masyarakat dan muncul di neraca. Di sisi lain, LAZ Rumah Zakat menyajikan dana non halal ke dalam akun berbeda dengan dana zakat, infak dan amil. Ketiga lembaga tersebut mengakui dana non halal sesuai dengan tanggal pada rekening koran dan jumlahnya (pengukuran) sesuai dengan jumlah yang tertera dalam rekening koran.

Pengungkapan atas dana non halal dilakukan oleh ketiga lembaga tersebut. Pengungkapannya lebih mengarah pada alasan (darurat) mengapa muncul dana non halal. LAZ Yatim Mandiri misalnya, lembaga tersebut mengungkapkan bahwa penggunaan rekening bank konvensional tidak dapat dihindari karena 90\% donator menggunakan bank konvensional. Oleh karena itu, LAZ Yatim Mandiri menggunakan jasa bank konvensional untuk mempermudah dalam menghimpun dana.

Fakta internasional dapat dilihat pada jurnal Harianto (2016), dimana dia melakukan penelitian tentang akuntansi untuk zakat. Objek penelitiannya adalah baitulmal di provinsi Aceh. Penelitiannya menggunakan metode perbandingan antara standar akuntansi syariah dengan data berupa laporan keuangan baitulmal. Di dalam penelitiannya, dia menemukan perlakuan akuntansi dana 
non-halal. Penyajian dana non-halal dengan dana amil lainnya di dalam balance sheet tidak dilakukan pemisahan. Rasid, Rahman, \& Ismail (2011) melakukan penelitian pada institusi Malaysia. Penelitian tersebut mencoba untuk mengeksplorasi perbedaan antara Sistem Akuntansi Manajemen pada Institusi Keuangan Konvensional dan Syariah di Malaysia. Rasid et al., 2011 menyatakan bahwa non-halal income dihitung dan tidak dimasukkan kedalam statement pendapatan. -Non-halal income ini dimasukkan ke dalam akun khusus yang kemudian didistribusikan, tidak untuk kepentingan pribadi melainkan untuk kepentingan publik. Non-halal income ini dapat berupa bunga yang didapat dari kontrak dengan bank konvensional.

Maali, Casson, \& Napier (2006), yang melakukan penelitian terhadap 29 bank syariah di 16 negara, menyatakan bahwa bank syariah pada umumnya tidak mengungkapkan aktivitas-aktivitas yang mengundang kritik oleh masyarakat. Aktivitas tersebut salah satunya adalah un-lawful transaction atau transaksi yang diharamkan oleh syariah. Wan Amalina Wan Abdullah, Percy, \& Stewart (2013) menemukan bahwa terdapat 5 bank syariah dari 23 sample bank syariah mengungkapkan lawfulness of earnings. Tiga bank syariah Malaysia mengungkapkan bahwa lawfulness of earnings telah dibuang berdasarkan persetujuan SSB dan dua lain mengkonfirmasikan tidak terbentuknya lawfulness of earnings.

Peneliti melakukan refleksi atas beberapa penelitian tentang akuntansi syariah tersebut, bahwa dalam instansi syariah (beberapa disebutkan di atas) pun tidak ada pemisahaan akun antara yang halal dengan yang haram. Namun, mereka sudah mulai menganggap bahwa pendapatan bunga tidak masuk komponen laba. Mereka memasukkannya ke dalam komponen dana di laporan neraca dan mengungkapkan secara "jelas" bahwa dana di laporan neraca termasuk di dalamnya dana non halal. Hanya satu instansi (dari penelitian di atas) saja yaitu LAZ Rumah Zakat yang memisahkan antara dana halal dan haram. Walaupun instansi tersebut diatas menggunakan akuntansi syariah, namun tidak dilakukan secara penuh.

Perusahaan swasta seperti PT Cendana Teknika Utama (perusahaan berbasis IT) memiliki perlakuan akuntansi yang "unik" dalam memperlakukan pendapatan bunganya. Perusahaan tersebut memperlakuan bunga simpanan layaknya hutang. Akun Hutang Pendapatan Bunga muncul dalam laporan neraca. Hal ini menjadi fenomena penelitian ini, yaitu perlakuan akuntansi yang berbeda dengan standar akuntansi yang telah ada. Fenomena ini memunculkan pertanyaan pada diri peneliti "mengapa bunga bank diperlakukan sebagai hutang?". Dalam teori interaksionisme simbolik, perlakuan akuntansi merupakan aksi yang didasari oleh makna suatu simbol. Simbol disini ialah bunga bank itu sendiri. Maka penting bagi peneliti untuk memahami bagaimana simbol dan makna pendapatan bunga bank bagi manajer PT CTU?

\section{METODE PENELITIAN}

Penelitian ini bertujuan untuk memahami makna bunga bank menurut manajer PT CTU. Peneliti menggunakan 5 informan yang terbagi atas 1 kepala divisi accounting, 3 divisi accounting, dan 1 direktur keuangan perusahaan. Peneliti memilih informan tersebut karena peneliti pernah bekerja satu divisi dengan 3 dari 5 informan tersebut selama kurang/lebih 6 bulan. Peneliti memilih PT CTU sebagai situs penelitian dengan merujuk pada beberapa alasan mendasar, yaitu (1) PT CTU memiliki cara (action) "unik" -sebagaimana peneliti pernah terlibat dalam praktik- dalam memperlakuan pendapatan bunga, (2) PT CTU merupakan perusahaan swasta yang memiliki "budaya" islami seperti berbondong-bondong jamaah di masjid, (3) PT CTU mendukung dilakukannya penelitian tentang simbolik interaksionisme dilihat dari makna atas pendapatan bunga yang dihadirkan melalui interaksi dan menjadi dasar diterapkannya perlakuan akuntansi hutang 
Makna

Bunga

Bank...

772 pendapatan bunga, (4) Mudahnya akses untuk mendapatkan persetujuan melakukan penelitian.

Pendekatan yang digunakan oleh peneliti adalah interpretif dengan metode interaksionisme simbolik. Dimensi ontologi yang ada pada interpretif dapat membantu peneliti memahami dalam perspektif subjektif. Adanya dimensi epistemologi pada interpretif - terkait dengan interaksi peneliti dengan apa yang diteliti - dapat membantu peneliti memahami lebih dalam melalui sebuah interaksi. Di sisi lain, dimensi metodologi dalam paradigma interpretif mempermudah peneliti dalam meningkatkan akurasi dan keandalaan melalui verifikasi secara langsung. Interaksionisme simbolik dianggap relevan digunakan karena pada bahasan interaksionisme simbolik, interaksi sosial merupakan pokok kajian dari ilmu sosial yang perlu adanya pemahaman mengenai makna atas "sesuatu" yang ada dibalik sebuah interaksi (lihat Irianto, 2015: 2; Muhadjir, 2011:220; Razak, Ludigdo, Sukoharsono, \& Thoyib, 2011; Triyuwono, 2015: 42). "Sesuatu" yang dimaksud adalah simbol. Simbol tersebut diberi makna oleh subjek. Simbol yang yang bermakna ialah simbol yang dapat membangkitkan respon yang sama antara subjek satu dengan subjek yang dituju (Ulfatin, 2015: 102). Misalkan dalam sebuah tempat nongkrong sebuah grup remaja sedang ngopi. Kemudian salah seorang remaja berkata "cabut yuk!", maka serentak remaja lain langsung berkemas dan segera meninggalkan temat nongkrong. Hal ini dikarenakan kata "cabut yuk" dimaknai sama oleh remaja-remaja tersebut, yaitu "pergi meninggalkan tempat tersebut".

Pendekatan ini biasa digunakan dalam bidang anthropologi yang mengkaji tentang interaksi individu atau kelompok yang memunculkan makna dan simbol, kemudian dilakukan sebuah keputusan yaitu berupa tindakan/action (Irianto, 2015: 2). Menurut Blumer (dalam Irianto, 2015: 5) terdapat tiga premis dalam teori ini, (1) tindakan manusia terhadap sesuatu berdasarkan makna yang ada pada "sesuatu" itu bagi mereka, (2) makna tersebut muncul dari "interaksi sosial seseorang dengan orang lain", dan (3) makna tersebut disempurnakan melalui proses penafsiran pada saat "proses interaksi sosial" berlangsung. Maksud dari "Sesuatu" ialah berupa realitas sosial; seperti tindakan seseorang, fenomena alam, maupun fenomena artifisial.

Selanjutnya Irianto (2015) menjelaskan bahwa sebelum melakukan pemaknaan atas suatu simbol, actor melakukan interaksi dan komunikasi. Kemudian sebuah tindakan dilakukan oleh actor. Sejalan dengan penelitian ini, maka manajer PT Cendana Teknika Utama melakukan interaksi dan komunikasi, kemudian memunculkan simbol berupa pendapatan bunga bank. Dari simbol tersebut, peneliti mencoba memahami maknanya. Akhirnya, dari makna tersebut dibuatlah keputusan perlakuan akuntansi pendapatan bunga bank sebagai hutang. Oleh karena itu, sebenarnya tindakan manusia bukan disebabkan karena kekuatan luar maupun dalam, akan tetapi berdasarkan pada pemaknaan atas simbol melalui proses interaksi dan komunikasi.

Peneliti menggunakan pendekatan simbolik interaksionisme karena temuannya akan lebih luas dan menjadi sebuah drama yang "menyenangkan". Peneliti pernah mendapatkan pertanyaan "mengapa tidak memakai Etnometodologi atau Fenomenologi misalnya?". Menurut peneliti, memang perlakuan akuntansi merupakan praktik yang "berulang-ulang", namun sudah terlihat jelas praktinya. Etnometodologi mencoba mengungkap praktik yang tidak terlihat, oleh karena itu peneliti tak menggunakan etnometodologi.

Di sisi lain, Fenomenologi dan Simbolik Interaksionisme sama-sama "menghasilkan" makna. Misalnya, fenomenologi transedental yang mencoba mengupas esensi (hakikat) dari "sesuatu" (Kuswarno, 2009: 44). Sebenarnya, teori simbolik interaksionisme "tercipta" juga tidak lepas dari pakar fenomenologi (Irianto, 2015: 2). Akan tetapi, luas dari simbolik interaksionisme tidak hanya pada makna simbol semata, namun juga pada interaksi dan tindakan yang diambil oleh actor. Hal inilah yang menjadikan peneliti "penasaran" untuk menggunakan pendekatan Simbolik Interaksionisme. 
Pengumpulan data yang digunakan oleh peneliti meliputi metode observasi, wawancara, dan dokumentasi. Pertama. wawancara tidak terstruktur dilakukan dengan cara pertanyaan yang diajukan tidak acak atau alur pertanyaan tergantung pada jawaban/minat informan. Gunawan (2015: 164) menjelaskan bahwa wawancara tidak terstruktur terkadang diikuti dengan kata kunci, agenda maupun beberapa daftar topik, agenda maupun beberapa daftar topik, namun tidak ada pertanyaan yang ditetapkan sebelumnya. Wawancara tidak terstruktur ini bertujuan untuk menggali lebih dalam tentang realitas yang tidak nampak oleh panca indra. Peneliti melakukan wawancara dengan 5 (lima) informan memiliki posisi di PT CTU yaitu direktur keuangan dan divisi accounting. Kedua, peneliti juga membaur (observasi) menjadi satu dengan para pelaku dan menjadi bagian dari PT CTU untuk mendapatkan informasi tentang budaya islami di PT CTU. Misalkan, peneliti mengamati karyawan yang berbondong-bondong jamaah ke masjid. Ketiga, peneliti melakukan dokumentasi atas data-data sekunder. Teknik ini guna mendapatkan informasi tentang perlakuan akuntansi pendapatan bunga bank. Data tersebut berupa laporan keuangan PT CTU.

Miles \& Huberman (2014: 16) mengemukakan bahwa setidaknya terdapat tiga langkah untuk menganalisi data kualitatif, yaitu: reduksi data, penyajian data dan menarik kesimpulan atau verifikasi. Data pada penelitian ini kemudian dilakukan analisis dengan diawali reduksi data, penyajian data, sampai dengan analisi interaksionisme simbolik. Adapun analisis interaksionisme simbolik yang digunakan pada penelitian ini ialah (1) menterjemahkan tulisan, (2) menafsirkan, dan (3) memaknakan (Ulfatin, 2015: 104).

\section{HASIL DAN PEMBAHASAN}

PT. Cendana Teknika Utama namanya, merupakan perusahaan yang bergerak pada bidang IT. PT CTU merupakan perusahaan IT yang berdiri pada tahun 1998. Sebelumnya, PT CTU berbadan hukum CV, yang bernama CV CNk. PT CTU memiliki budaya yang sangat unik. Walaupun PT CTU bukan merupakan instansi syariah, namun memiliki budaya islami yaitu sholat 5 waktu berjamaah di masjid. Suara adzan dari Masjid Abu Dzar Al-Ghifari terdengar merdu sampai ke area kantor PT CTU. Apabila suara adzan mulai berkumandangan, para karyawan secara "otomatis" menghentikan segala aktivitas "dunia"nya. Beberapa karyawan laki-laki mulai mengenakan perlengkapan sholatnya seperti kopyah. Mereka (para karyawan laki-laki) berbondong-bondong menuju Masjid Abu Dzar Al-Ghifari yang berlokasi tidak jauh dari kantor PT CTU di Griyashanta Malang.

PT CTU juga memiliki fasilitas mushola, namun meski begitu, karyawan laki-laki tetap pergi ke Masjid kecuali saat hujan turun. Fasilitas mushola tersebut, menjadi "rumah suci" bagi karyawan perempuan dan karyawan laki-laki yang berhalangan pergi ke Masjid. Budaya seperti ini sudah muncul sangat lama. Sebelumnya hanya sedikit yang pergi ke Masjid untuk sholat 5 waktu, namun dengan tumbuhnya kesadaran dalam diri karyawan PT CTU, kegiatan sholat berjamaah di Masjid menjadi "populer" dan membudaya. Tanpa adanya perintah dari pihak PT CTU, para karyawan sadar akan kewajibannya untuk berjamaah di Masjid. Selain budaya islami, perusahaan tersebut juga memiliki komitmen untuk tidak mencampur (memisahkan) dan menggunakan bunga bank sejak pertama kali berdiri. Prinsip-prinsip Islam menjadi landasan dalam membuat keputusan dan kebijakan perusahaan. Hal ini dikarenakan shareholder yang beragama Islam semua. Peneliti menemukan dualitas makna bunga bank yaitu:

Makna bunga bank sebagai imbalan atas jasa. Makna merupakan maksud dari lubuk hati informan terhadap "sesuatu". Makna bunga bank didapat melalui sebuah interaksi antar beberapa orang. Seperti halnya dalam teori interaksi simbolik, makna terbentuk dan disempurnakan melalui interaksi antar individu atau kelompok. Berdasarkan interaksi yang telah terjadi anatara informan dengan 
Makna

Bunga

Bank...

774 dosen TA-nya, bunga bank memiliki makna sebagai imbalan atas jasa. Imbalan berupa pandapatan bunga bank merupakan bentuk materialitas. Imbalan sendiri sebenarnya memiliki beberapa bentuk, yaitu materi dan non-materi. Materi ialah segala sesuatu yang nampak dan berbentuk fisik, sedangkan non-materi merupakan sesuatu yang tidak terlihat dan mungkin hanya bisa dirasakan. Imbalan non-materi contohnya ialah rasa bahagia, rasa puas ataupun pahala. Pahala merupakan imbalan non-materi yang hanya Allah SWT lah yang memberikannya. Hal ini terjelaskan dalam Al-Qur'an surat An Nisa ayat 114.

Makna bunga bank sebagai imbalan atas jasa sejalan dengan teori akuntansi konvensional. Dalam pernyataan pendapatan merupakan hasil atas sebuah pengorbanan, dikatakan pengorbanan tentunya karena memiliki risiko. Risiko menurut KBBI merupakan akibat yang kurang menyenangkan atau merugikan dari sebuah tindakan. Risiko ketika menyetor dana [resiko] ke Bank dalam bentuk simpanan adalah berupa potongan admin dan pajak. Resiko lainnya adalah jika menyetor dana ke Bank Konvensional khususnya, maka risiko dana tersebut digunakan untuk sesuatu yang tidak halal.

Imbalan atas jasa tersebut boleh digunakan sesuai dengan pernyataan informan sebagai berikut:

"lek aku selama ini sebagai other income Mas, lek aku pribadi lho." Jawab Mas Doni

Jika suatu pendapatan dikatakan pendapatan lain-lain maka itu merupakan hak perusahaan baik digunakan untuk pribadi atau lainnya. Hal ini merupakan pandangan informan sesuai dengan prinsip akuntansi konvensional. Berbeda halnya jika dianggap sebagai pendapatan non halal maka tidak boleh digunakan untuk pribadi. Pemahaman konvensional ini juga masih dihayati oleh beberapa informan. Beberapa informan tidak mempedulikan bunga bank pada rekening mereka masing-masing. Ada yang berfikiran bahwa nilainya kecil, sehingga tidak ada masalah kalau tercampur dengan uang pribadi. Pemikiran ini sesuai dengan qiyas beberapa ulama. Qiyas merupakan analogi antara sesuatu yang berbeda sifatnya. Bentuk qiyas dalam konteks ini adalah bunga bank disamakan dengan hukum air, dimana air suci dibaskom untuk wudlu jika terkena kotoran cicak maka hukumnya tetap suci selama tidak berubah warna, bau dan rasa. Bunga bank juga dianalogikan dengan hukum air tersebut, bunga bank yang sedikit tercampur dengan uang hasil operasional yang halal maka hukumnya tetap halal.

Makna bunga bank sebagai kewajiban untuk kegiatan sosial. Kewajiban merupakan sesuatu yang harus dibayarkan. Kewajiban dapat berupa materi maupun non materi. Kewajiban materi misalnya kewajiban membayar hutang uang maupun barang, sedangkan non materi contohnya seperti kewajiban beribadah ataupun menunaikan tugas. Bunga bank bagi manajer PT CTU merupakan kewajiban perusahaan untuk dikeluarkan dalam bentuk fasilitas umum. Kewajiban ini merupakan sesuatu yang diyakini oleh PT CTU. Hal tersebut terjelaskan dalam informasi yang diberikan oleh salah satu informan sebgai berikut:

“......dikeluarkan...nanti dadi biasane alokasine iku kan gawe keperluan sosial, dadi koyok nyumbang faskum, fasilitas umum di desa" Terang Mas Doni

Makna kewajiban ini muncul karena shareholder yang mayoritas Islam dan sejak awal berdiri berkomitmen untuk memisahkan bunga bank dari kegiatan operasional perusahaan. Kewajiban ini bisa dikatakan sebagai hutang, hutang yang harus dibayar dalam bentuk fasilitas umum.

"....dari awal berdiri kita sudah berkomitmen untuk tidak menggunakan dan memisahkan bunga bank dari operasional perusahaan” Tegas Pak Rifa’i

PT CTU tidak ingin menggunakan bunga bank karena itu termasuk sesuatu yang haram. Informan tidak memaparkan dampak bunga bank jika digunakan, 
namun hanya menjelaskan bahwa itu sesuatu yang haram. Dalam islam, sesuatu yang haram tidak boleh dikonsumsi ataupun dipraktikan. Direktur Keuangan PT CTU meyakini keharaman tersebut tanpa mencari tahu dampak buruk jika digunakan. Hal ini merupakan bentuk totalitas dalam mengamalkan nilai-nilai dan ajaran Islam. Allah berfirman dalam Al Hasyr ayat 7 “...Apa yang diberikan Rasul kepadamu, maka terimalah. Dan apa yang dilarangnya bagimu, maka tinggalkanlah...”. Ayat ini menunjukkan bahwa tahu atau tidak penyebab dibolehkan/ tidaknya sesuatu, seorang muslim harus mematuhi hukum itu.

“..ya nggak lihat dampaknya, misal sampean tahu babi itu haram, ya tak perlu cari tahu kenapa haram dahulu untuk meyakininya, kalau haram ya haram..titik! jangan dimakan.” Tegas Pak Rifai.

Berdasarkan pada penjelasan informan terkait dampak menggunakan bunga bank untuk kepentingan pribadi, manusia hanya perlu meyakini apa yang ada pada Ajaran Islam. Hal tersebut dikarenakan dalam memeluk agama islam dianjurkan dalam mode kaffah. Kaffah yang dimaksud ialah totalitas atau tanpa ragu sedikit pun. Islam adalah agama yang rahmatan lil alamin. Islam mencakup segala aspek kehidupan sehingga tidak perlu lagi ragu terhadap setiap ajaran-ajaran islam. Namun, tentu saja tetap harus memahami dalil dari tiap ajaran yang dipelajari. Hal tersebut guna untuk menghindari "kesesatan" dalam beragama.

Meskipun bunga bank ini haram, namun diperbolehkan untuk menggunakannya demi kepentingan sosial. Beberapa ulama mengarahkan penggunaan bunga bank hanya untuk kepentingan sosial saja (Hisamuddin, 2014). Salah satu informan mengetahui hal tersebut dari interaksi dalam suatu pengajian. Tapi tidak dapat dipungkiri pada PT CTU bahwa kuasa Direktur lah yang memperkuat pemahaman atau pemikiran tersebut. Semua informan mengamini bahwa bunga bank hanya boleh untuk kepentingan sosial. Berikut beberapa pernyataan dari informan:

"dari islam sendiri sudah tegas tidak boleh dipakai, saya pernah denger hanya boleh untuk kepentingan umum.” Jelas Mas Lucky

"he'em gae sosial, ndak dipakai untuk perusahaan, mek gae sosial ngono iku" Terang Mbak Nopi

PT CTU mengakumulasi pendapatan bunganya kedalam hutang sehingga akan menumpuklah menjadi nilai yang sangat besar. Dari nilai yang terakumulasi tersebut kemudian akan disalurkan untuk kepentingan sosial. Kepentingan sosial bisa dalam bentuk misalnya memperbaiki jalan. Biasanya Direktur Utama dan Direktur Keuangan yang mencari penerima dana tersebut. Hal tersebut diterangkan sendiri oleh Direktur Keuangan:

"Yang banyak berperan untuk mencari penerima hutang pendapatan bunga, ya saya dan Pak Aji."

Menurut informan alasan mengapa hanya Direktur saja yang mencari penerima dana karena mereka telah memiliki banyak link dan akan lebih mudah proses pengurusannya.

"maksud e lek kene jaluk dewe kudu nggawe makalah dan ribet, lek bapak e kan wes akeh link dan paham lokasi ndi-ndi e." Terang Mbak Nopi

Dana yang sudah terakumulasi satu tahun, biasanya tidak habis tahun itu juga. Berdasarkan informasi dari informan, misalkan tahun ini terkumpul 1juta rupiah, maka bisa jadi yang terpakai hanya 900ribu rupiah, sisanya akan diakumulasi lagi. Berikut pernyataan Mas Agus tentang hal tersebut: 
Makna

Bunga

Bank...

776 "jadi selama iki sih...lek pendapatan bunga iku diakumulasi setahun, dikumpulkan, terus ketika opo, kan gak setiap tahun itu pasti keluar habis semua, contoh misalnya tiap bulan dapat 100 ribu ya, kan setahun berarti 1,2jt, jadi gak mesti habis 1,2 jt untuk tahun itu,..."

Dana yang keluar tergantung sebesar apa kebutuhan dari pihak penerima dana. Dana tersebut biasanya diberikan dalam bentuk uang cash. PT CTU tidak ingin ribet untuk membelikan bahan-bahan yang dibutuhkan penerima dana.

Berdasarkan makna bunga bank sebagai kewajiban ini, berarti bunga bank tidak termasuk ke dalam hasil dari suatu upaya. Niat perusahaan memberikan uangnya ke Bank Konvensional adalah hanya untuk menyimpan saja. Dalam konsep islam barang titipan tidak boleh digunakan atau dimanfaatkan. Akad titipan atau yang sering dikenal dengan istilah wadi'ah tentunya hanya sebuah titipan dimana orang yang dititipi tidak boleh menggunakan barang tersebut (Muslich, 2012: 455).

Sehingga, apabila digunakan oleh orang yang dititipi dan menghasilkan sesuatu, maka pemilik dana tidak berhak menerimanya. PT CTU tentu menyadari hal ini, sehingga tidak menggunakan bunga bank untuk kepentingan pribadi. Makna ini sangat bertentangan dengan makna bunga bank sebelumnya.

Kekuasaan shareholder berdampak pada dominasi makna bunga bank. Makna bunga bank sebagai kewajiban untuk kegiatan sosial terbentuk melalui interaksi antar pihak yang bersangkutan. Pihak tersebut ialah pihak shareholder dengan divisi accounting. Makna disempurnakan melalui penafsiran dan terjadi pertukaran ketika interaksi berlangsung, namun dengan dominasi dari shareholder maka terciptalah makna yang utuh dan disesuaikan dengan landasan PT CTU yaitu nilai-nilai Islam. Dalam simbolik interaksionisme, makna disesuaikan dengan lingkungan sekitarnya. Budaya dan lingkungan yang islami dari PT CTU inilah yang juga memperkuat dominasi "makna bunga bank: kewajiban untuk kegiatan sosial".

Walaupun terjadi konflik perbedaan pemikiran atas makna, mereka yang tidak memiliki kuasa tetap tidak dapat mendominasikan makna yang dimilikinya. Sistem Top-Down yang dianut PT CTU menjadikan kuasa milik Direktur. Hal itu diungkapkan oleh Mas Agus:

"sistem kita kan top-down langsung dari direksi..."

Shareholderyang mayoritas islam dan memiliki keyakinan untuk tidak menggunakan bunga bank, menciptakan makna yang kuat tentang bunga bank. Topdown merupakan istilah dimana segala keputusan ada pada pihak atasan yaitu direktur atau shareholder. Hal ini tentunya menjadikan shareholder atau direktur pada posisi paling tinggi. Kekuasaan shareholder sangat mempengaruhi segala aspek pada perusahaan tersebut. Pembentukan makna bunga bank misalnya, walaupun ada berbagai makna yang dimiliki tiap-tiap individu maupun kelompok di perusahaan tersebut, namun hanya shareholder yang dapat mendominasi dalam proses pertukaran makna tersebut.

Beberapa informan menjelaskan bunga bank dengan pemikiran masingmasing, beberapa cenderung ke arah konvensional. Namun ketika peneliti bertanya “mengapa PT CTU memperlakukannya sebagai hutang?", informan mengubah pemikirannya. Pemikiran tersebut disesuaikan dengan kondisi lingkungan PT CTU. Artinya mereka sudah berinteraksi dengan petinggi perusahaan dan mendapatkan pemikiran yang paling kuat di PT CTU tersebut. Kepemilikan saham inilah yang mengontrol dan memiliki kuasa dalam segala kebijakan, aktivitas maupun tindakan perusahaan (Amiruddin, 2014; Foucault, 1982; Nuraeni \& Mentari, 2013). Makna inilah yang menjadi dasar diperlakukannya bunga bank sebagai hutang. Teori simbolik menyatakan bahwa keputusan atau tindakan dilakukan berdasarkan makna. Makna tersebut muncul karena suatu interaksi dan tentunya disempur- 
nakan dengan melihat situasi, kondisi, bahkan budaya (Singelmann, 1972). Makna bunga bank sebagai hutang untuk kegiatan sosial, kemudian menciptakan inovasi bagi manajer dalam hal perlakuan akuntansinya. Dimana perlakuan akuntansi bunga bank sebagai hutang ini adalah sebagai tindakan atau keputusan manajer.

PT CTU berinovasi dalam hal perlakuan akuntansi bunga bank karena landasan makna yang digunakan berbeda dengan standar akuntansi yang ada. PT CTU menggunakan konsep hutang dalam mencatat pendapatan bunganya. Perlakuan akuntansi yang digunakan PT CTU telah berjalan sejak pertama kali perusahaan ini berdiri, yaitu tahun 1996. Inovasi perlakuan akuntansi oleh PT CTU semacam ini terjadi sebelum akuntansi syariah lahir. Pada saat itu tentunya standar akuntansi syariah belum ada. Akhirnya manajer PT CTU bertukar makna dan diambilah tindakan yaitu menciptakan perlakuan akuntansi pendapatan bunga sebagai hutang. Makna yang dominanlah yang berperan besar dalam menciptakan inovasi tersebut.

Pemisahan bunga bank dengan kegiatan operasional ini sama dengan konsep yang dimiliki akuntansi syariah. Dalam akuntansi syariah, antara halal dan haram haruslah dipisahkan dan tidak dimasukkan kedalam kegiatan operasional (Ghofur, 2008). PT CTU memiliki metode pengakuan Bunga Bank yang berbeda dengan standar akuntansi baik syariah maupun konvensional. Bunga bank tersebut diakui oleh PT CTU sebagai hutang. Makna yang melekat pada bunga bank itulah yang mendorong manajer PT CTU untuk mengakuinya sebagai hutang. Kemudian munculah akun ciptaan yaitu Hutang Pendapatan Bunga. Hutang Pendapatan Bunga ini diakui ketika saldo bunga bank masuk di rekening bank PT CTU. Hutang Pendapatan Bunga ini diukur sebesar nilai yang tampak pada rekening koran perusahaan. Hal ini dapat dikatakan PT CTU menggunakan metode setara kas dalam pengukurannya. Sebenarnya memang tidak ada perbedaan dalam pengukuran pendapatan bunga baik konvensional maupun syariah.

“..nah iku langsung kita akui sebagai hutang dan diakui pada saat masuk ya, masuk ke bank kita,...” Jawab Mas Lucky

“..terus yang kedua terkait dengan pengukuran ya, diakui sejumlah yang masuk, kebetulan disini pakai rupiah ya, jadi diakui sebesar nilai masuk, delok e lewat rekening Koran, Kemudian Penyajiannya disajikan sebagai hutang di Neraca..” Tanggap Mas Lucky

Hutang Pendapatan Bunga disajikan di Laporan Neraca, berbeda dengan konsep syariah, di sajikan pada Laporan Qardhul Hassan. Di sisi lain, konsep konvensional menyajikan pendapatan bunga di Laporan Laba Rugi. Hal ini merupakan dampak dari inovasi penciptaan akun Hutang Pendapatan Bunga. Hutang tersebut oleh PT CTU dimasukkan ke dalam kategori Kewajiban Lancar Non-Usaha. Kewajiban Lancar Non-Usaha artinya kewajiban tersebut didapat dari kegiatan diluar operasional dan tentunya perusahaan harus segera melunasinya. Jangka waktu pelunasan adalah satu tahun. Bunga bank yang disajikan pada kategori Kewajiban Lancar Non-Usaha adalah sebagai pengingat bahwa dana ini harus segera dikeluarkan. Bunga bank ini oleh PT CTU juga dipahami sebagai nilai yang didapat dari kegiatan diluar kegiatan operasional mereka.

\section{SIMPULAN}

Berdasarkan hasil wawancara mendalam dengan para informan, dilanjutkan dengan analisis interaksionisme simbolik, terdapat beberapa simpulan. Metode interaksionisme simbolik dalam penelitian ini menghasilkan dua makna bunga bank yang saling bertentangan. Pertama, makna bunga bank sebagai kewajiban untuk kegiatan sosial. Hal ini berarti perusahaan memiliki kewajiban untuk mendistri- 
busikan dana bunga bank yang mereka miliki kepada pihak yang membutuhkan bantuan sosial seperti perbaikan fasilitas umum. Jatuh tempo selama satu tahun dan tidak boleh lebih dari itu. Kedua, makna bunga bank sebagai imbalan atas jasa. Artinya bunga bank ini merupakan hasil dari upaya menyetorkan modal di bank konvensional. Oleh karena itu dana bunga bank pada makna ini, boleh digunakan untuk kepentingan pribadi. Kedua makna ini sangat bertentangan.

Sisi kanan bunga bank tidak boleh digunakan untuk pribadi karena merupakan kewajiban yang hanya boleh digunakan untuk sosial. Sisi kiri bunga bank boleh dinikmati pribadi karena hasil dari upaya. Kedua makna ini tentunya saling "bertabrakan" ketika interaksi dan pertukaran makna terjadi. Hanya ada satu makna yang kuat dan mendominasi di PT CTU yaitu makna bunga bank sebagai kewajiban untuk kegiatan sosial. Hal ini dikarenakan makna tersebut memiliki kekuatan dari Direktur Keuangan PT CTU. Oleh karena itu, dari makna yang dominan itu diputuskanlah untuk memperlakukan bunga bank sebagai hutang pendapatan bunga. Hasil ini memberikan khasanah keilmuan baru, bahwa setiap institusi melakukan tindakan bukan hanya karena sebuah peraturan namun juga adanya makna atas simbol yang didukung dengan budaya perusahaan. Tidak semua institusi akan menggunakan standar umum sebagai acuan dalam "berakuntansi" namun bisa jadi mereka melakukan inovasi sesuai dengan makna yang telah terbentuk dan disempurnakan melalui sebuah interaksi.

\section{DAFTAR PUSTAKA}

Abedifar, P., P. Molyneux, and A. Tarazi,. 2013. "Risk in islamic banking". Review of Finance. Vol. 17. No. 6. hlm. 2035-2096.

Ahmad, A.U.F. and M.K. Hassan. 2007. "Riba and Islamic Banking". Journal of Islamic Economics, Banking and Finance. Vol. 3. No. 1. Hlm. 1-33.

Amiruddin, S. 2014. "Jaringan Sosial Pemasaran Pada Komunitas Nelayan Tradisional Banten". Research and Learning in Sociology and Anthropology Vol. 6. No. 1. hlm. 106-115.

Beck, T., A. Demirgüç-Kunt, and Merrouche, O. 2013. "Islamic vs. conventional banking: Business model, efficiency and stability". Journal of Banking and Finance. Vol. 37. No. 2. hlm. 433-447.

Bohusova, H.and D. Nerudova. 2009. "US GAAP and IFRS Convergence in the Area of Revenue Recognition". Economics \& Management, 12-19.

Chong, B.S. and M.H. Liu. 2009. "Islamic banking: Interest-free or interest-based?" Pacific Basin Finance Journal. Vol. 17 No. 1. hlm. 125-144.

Foucault, M. 1982. "The Subject and Power". Critical Inquiry Vol. 8. No. 4. hlm. $777-795$.

Ghofur, A.A. 2008. "Sejarah Perkembangan Hukum Perbankan Syariah di Indonesia dan Implikasinya bagi Praktik Perbankan Nasional". Jurnal Ekonomi Islam. Vol. II. No. 2. hlm 14.

Gunawan, I. 2015. "Metode Penelitian Kualitatif: Teori dan Praktik". Bumi Aksara. Jakarta.

Harianto, S. 2016. "Accounting For Zakat on Income Critical Study Based on Government Regulation (Case Study in Aceh Province of Indonesia)". International Journal of Business, Accounting and Management. Vol. 1. No. 3. hlm. $47-52$.

Hisamuddin, N. 2014. "Persepsi, Penyajian dan Pengungkapan Dana Non Halal pada BAZNAZ dan PKPU Kabupaten Lumajang”. Jurnal Zakat Dan Wakaf. Vol. 1. No. 1. hlm. 1-36.

Irianto, A.M. 2015. "Interaksionisme Simbolik". Gigih Pustaka Mandiri. Semarang.

Kuswarno, E. 2009. "Fenomenologi: Konsepsi, Pedoman dan Contoh Penelitian". Widya Padjadjaran. Bandung. 
Maali, B., P. Casson, and C. Napier. 2006. "Social reporting by Islamic banks". Abacus. Vol. 42. No. 2. hlm. 266-289.

Miles, M.B. and A.M. Huberman. 2014. “Analisis Data Kualitatif”. Universitas Indonesia Press. Jakarta.

Muhadjir, N. 2011. "Metodologi Penelitian”. Rake Sarasin. Yogyakarta.

Muslich, A.W. 2012. "Fiqh Muamalat". Amzah. Jakarta.

Nuraeni, A. and R. Mentari. 2013. "Komodifikasi Dai di Televisi/ : Kajian Ekonomi Politik Media". Jurnal Komunikator. Vol. 5. No. 21. hlm.70-82.

Rasid, S.Z.A., A.R.A. Rahman, and W.K.W. Ismail. 2011. "Management accounting systems in Islamic and conventional financial institutions in Malaysia". Journal of Islamic Accounting and Business Research. Vol 2. No. 2. hlm. 153-176.

Razak, A., U. Ludigdo, G.Sukoharsono, and A. Thoyib. 2011. "Perilaku Kuasa Eksekutif dan Legislatif Dalam Proses Anggaran Pemerintah Daerah: Perspektif Interaksionisme Simbolik". Jurnal Akuntansi Multiparadigma. Vol. 2. No. 3. hlm 492-509

Roziq, A.and W. Yanti 2013. "Pengakuan, pengukuran, penyajian dan pengungkapan dana non halal pada laporan keuangan lembaga amil zakat". Jurnal Akuntansi Universitas Jember. Vol. 11. No. 2. hlm. 20-47.

Samsu, S. 2013. "Analisis Pengakuan dan Pengukuran Pendapatan Berdasarkan PSAK No. 23 Pada PT. Misa Utara Manado”. Jurnal EMBA. Vol. 1. No. 23. hlm. 567-575.

Septiono, A., Suhadak, and N. Sujana. 2015. "Kewajaran Laporan Keuangan (Studi Kasus Pada PT. Petrosida Gresik)”. Jurnal Administrasi Bisnis. Vol. 24. No. 1. hlm. 1-10.

Singelmann, P. 1972. "Exchange as Symbolic Interaction/ : Convergences between Two Theoretical Perspectives". American Sociological Review. Vol. 37. No. 4. hlm. 414-424.

Triyuwono, I. 2015. "Awakening the Conscience Inside: The Spirituality of Code of Ethics for Professional Accountants". Procedia - Social and Behavioral Sciences, 172, 254-261.

Ulfatin, N. 2015. "Metode Penelitian Kualitatif di Bidang Pendidikan: Teori dan Aplikasinya". Media Nusa Creative. Malang.

Wan Amalina Wan Abdullah, Percy, M. and Stewart, J. 2013. "Shari'ah disclosures in Malaysian and Indonesian Islamic banks". Journal of Islamic Accounting and Business Research. Vol. 4. No. 2. hlm. 100-131. 
